\title{
ADSORPTION OF Cd(II) BY CARBON PREPARED FROM PEELS AND STEMS OF KEPOK BANANA (MUSA PARADISIACA FORMATYPICA)
}

\author{
MERY NAPITUPULU, MUHAMMAD AL-GIFARY and DAUD K. WALANDA \\ Science Department, Faculty of Teacher Training and Education, Universitas Tadulako, \\ Jl. Soekarno Hatta Km. 9, Palu 94118, Indonesia \\ \Corresponding author: Mery Napitupulu,mery@untad.ac.id
}

Received October 18, 2018

\begin{abstract}
Carbon was produced from peels and stems of kepok banana and was characterized. Also, its Cd(II) adsorption ability was determined. The carbon material was prepared through two-stage carbonization. First, carbonization was carried out at $400{ }^{\circ} \mathrm{C}$ for 30 minutes, and then it was continued at $450{ }^{\circ} \mathrm{C}$ and $500{ }^{\circ} \mathrm{C}$ for 10 minutes. The results showed that the carbon content obtained after carbonization of banana peels at temperatures of $400{ }^{\circ} \mathrm{C}, 450{ }^{\circ} \mathrm{C}$ and $500{ }^{\circ} \mathrm{C}$ was $60.92 \%, 55.16 \%$ and $50.11 \%$, respectively, while that achieved from banana stems was $65.37 \%, 56.97 \%$ and $45.80 \%$, respectively. The moisture content of the carbon prepared from banana peels was 7.01\%, 5.37\% and 5.28\%, respectively, for each temperature level, while that of the carbon material made from banana stems was $4.93 \%, 4.17 \%$ and $3.44 \%$, respectively. The ash content of the banana peel carbon prepared at different temperature levels was $4.56 \%$, $7.23 \%$ and $11.04 \%$, respectively, and that of the banana stem carbon was $7.73 \%, 9.65 \%$ and $13.85 \%$, respectively. The highest iodine number of banana peel carbon $\left(450{ }^{\circ} \mathrm{C}\right)$ was $1006.74 \mathrm{mg} / \mathrm{g}$, while that of banana stem carbon $\left(450{ }^{\circ} \mathrm{C}\right)$ was $1019.43 \mathrm{mg} / \mathrm{g}$. Surface analyses were conducted using scanning electron microscopy - energy dispersive spectroscopy (SEM-EDS). The Cd(II) adsorbed by the carbon materials was measured using atomic absorption spectrometry (AAS). The results showed that increasing the weight of the adsorbent leads to an increased amount of adsorbed $\mathrm{Cd}(\mathrm{II})$.
\end{abstract}

Keywords: carbon, adsorption, banana peels, banana stems, SEM-EDS, AAS

\section{INTRODUCTION}

The development of the industrial world in the era of globalization has brought benefits in increasing human welfare. However, besides the benefits, the developments in the industrial world can also have a negative impact through the resulting wastes that pollute the environment. Environmental pollution is caused by uncontrolled waste produced by industries. One of the types of environmental pollution that has a great impact on human health is water and soil pollution. ${ }^{1}$

Water and soil pollution can be caused by the presence of heavy metals. Heavy metals leach into soil used for agricultural purposes and into water bodies and thus end up accumulating in humans and other living organisms, and are toxic as they cannot be broken down. Some heavy metal pollutants that are harmful to human and animal health are copper $(\mathrm{Cu})$, cobalt $(\mathrm{Co})$, lead $(\mathrm{Pb})$, cadmium $(\mathrm{Cd})$, silver $(\mathrm{Ag})$, nickel $(\mathrm{Ni})$, chromium $(\mathrm{Cr})$, mercury $(\mathrm{Hg})$, arsenic (As), zinc $(\mathrm{Zn})$, iron $(\mathrm{Fe})$ and manganese $(\mathrm{Mn}){ }^{2}$

Cadmium $(\mathrm{Cd})$ is one of the heavy metals that are often found in polluted water bodies. ${ }^{3}$ Based on the decision of the Indonesian Ministry of Environment, the standards for industrial wastewater quality restrict the maximum total cadmium to a level of $0.05 \mathrm{ppm}^{4}$ Although cadmium is an important metal in the industrial world, especially for the manufacture of $\mathrm{Ni}-\mathrm{Cd}$ cells in batteries, ${ }^{5}$ its presence in water must be eliminated because of its toxicity. Cadmium exposure can cause high blood pressure, testicular tissue damage, kidney damage and red blood cell damage. ${ }^{6}$

Several methods have been examined to diminish cadmium pollution. ${ }^{7-9}$ This study investigates the possibility to prepare a charcoal material from banana waste for its further use for cadmium adsorption. 
Banana peels have been reported to be successfully used as bio-sorbent with a contact time of 10 minutes. ${ }^{10}$ Porous carbon and porous carbon oxide have been prepared to remove methylene blue and cobalt $(\mathrm{Co}) .{ }^{11}$ The use of carbon, made from various materials, as an adsorbent to bind heavy metals has been described. ${ }^{12-14}$ Peanut shell activated carbon and amino-functionalized magnetic biochar obtained from wasted peanut hull have been found to adsorb chromium $(\mathrm{Cr})$ more efficiently than commercial carbon. ${ }^{15-16}$ The adsorption of a range of heavy metals, such as $\mathrm{Pb}^{2+}, \mathrm{Cd}^{2+}, \mathrm{Hg}^{2+}$ and $\mathrm{Ni}^{2+}$, by lignin precipitated from black liquor, which was carbonized at a temperature of $600{ }^{\circ} \mathrm{C}$, has been studied. ${ }^{17}$ The basic concept of carbon adsorption is to use the pore structure of carbon to bind metal ions; using a wider pore structure is more efficient because the adsorption power is determined by the particle surface area and pore structure. $^{18}$

The characteristics of carbon are determined by the conditions of its synthesis. One of the most important conditions of carbon synthesis is temperature. ${ }^{19}$ It was found that, by pyrolysis of banana pseudostem bio-waste at $300{ }^{\circ} \mathrm{C}$, the best adsorbent for $\mathrm{Cr}(\mathrm{VI})$ was created. ${ }^{20}$

The characteristics of carbon basically include the nature of its adsorption and its physical properties, including the total surface area, particle density and effective size. While the chemical properties of the surface (activated surface and sites) determine the occurrence of the adsorption process, as it tends to easily bind particles that have similar properties. The adsorption capacity of carbon depends on its surface area, while the pore diameter affects the adsorption process. Therefore, such parameters need to be taken into consideration for carbon production. $^{21}$

There are a number of methods to produce carbon capable to adsorb heavy metals. One of them is by thermal decomposition of organic materials through three stages: dehydration, carbonization and activation. ${ }^{22}$ Raw materials suitable for preparing carbon adsorbents can be obtained from organic materials with high cellulose content, such as coconut shells, wood fiber and agricultural waste containing high carbohydrates content. ${ }^{23}$ The synthesis of activated carbon from Procambarus clarkii shells, by using $\mathrm{K}_{2} \mathrm{C}_{2} \mathrm{O}_{4} \cdot \mathrm{H}_{2} \mathrm{O}$ as an activating agent, was reported to be successful due to the high $\mathrm{CO}_{2}$ adsorption capacity of the material. ${ }^{24}$ Another interesting research on waste lignocellulosic materials revealed the high potential of such materials to be used as adsorbents for $\mathrm{Ag}^{+}$ions. ${ }^{25}$

This study used raw materials derived from banana plants. Banana plants consist of stem, peelings, leaves, fruit, as well as the heart of the bananas. All the components of banana plants are rich in cellulose. Due to the high levels of cellulose, banana waste can be used to prepare adsorbents for heavy metals. ${ }^{26}$ Banana stems have carbon content, of around 49 grams in every 100 grams on dry weight. ${ }^{27}$ Previous research concluded that banana peels can be used for charcoal preparation, as the entire carbonization of banana peels reached $96.56 \%$ carbon content. The cellulose content in banana stems and banana peels make them good candidates to be used as adsorbents. $^{28}$ The synthesis and characterization of carbon materials developed from kepok banana (Musa paradisiaca formatypica) stems and peels, and their utilization for adsorption of $\mathrm{Cd}(\mathrm{II})$ ions are described in this study.

\section{EXPERIMENTAL}

\section{Synthesis}

Carbon was prepared by adopting the methods described in previous studies. ${ }^{12}$ Banana peels and stems were cleaned with water to remove the dirt. The samples were then cut into small pieces and dried for 5 days under direct sunlight, then placed in an oven at $105^{\circ} \mathrm{C}$ for 120 minutes. The resulted product was then burned (carbonization) in a furnace with a temperature of $400{ }^{\circ} \mathrm{C}$ for 30 minutes, then cooled at room temperature for 24 hours. The cooled sample was then burned again in the furnace at different temperature levels, of $450{ }^{\circ} \mathrm{C}$ and $500{ }^{\circ} \mathrm{C}$, for 10 minutes. The carbonized sample was smashed with a mortar and a pestle, and then sieved with an 80 mesh sieve. ${ }^{19,29}$

\section{Physical characterization}

The adsorption ability of the carbon obtained from banana stems and peels was assessed by atomic absorption spectrometry (AAS) (GBC 932 AA). The characterization of the surface and pore morphology performed with the help of SEM-EDS (scanning electron microscopy - energy dispersive spectroscopy) (JSM 63660 LA).

\section{Moisture content}

The evaporating dish was heated in an oven at 105 ${ }^{\circ} \mathrm{C}$ for 1 hour and then cooled in a desiccator. The dish was then weighed. 1 gram of carbon material was placed in the evaporating dish and then into the oven at $105{ }^{\circ} \mathrm{C}$ for 3 hours or until a constant mass was obtained. 


\section{Ash content}

The evaporating dish and the lid were heated in an oven at $105{ }^{\circ} \mathrm{C}$ for 1 hour, then cooled in a desiccator and weighed. Carbon weighing 1 gram was placed into the dish and the lid was closed. The cup was inserted into the furnace at a temperature of $815^{\circ} \mathrm{C}$ for 2 hours, then weighed until constant mass was noted. After obtaining a constant mass, the ash left in the dish was removed, and the dish and the lid were weighed again.

\section{Iodine number}

The carbon was heated in an oven at $115^{\circ} \mathrm{C}$ for 1 hour, then cooled in a desiccator. The cooled carbon $(0.5 \mathrm{~g})$ was placed into a dark closed flask. $50 \mathrm{~mL}$ of $0.1 \mathrm{~N}$ iodine solution was added to the carbon. The mixture was stirred for 15 minutes at room temperature, then transferred into a centrifugal tube and centrifuged until the sample drops and the liquid became clear. $10 \mathrm{~mL}$ of clear solution was put into a flask and titrated using $0.1 \mathrm{~N}$ sodium thiosulfate solution, and $1 \%$ starch solution was added as an indicator. The titration process was stopped when the blue color of the solution had disappeared.

\section{Morphological characterization of pores}

The produced carbon was then characterized as to its porous morphology by using SEM-EDS. The resulting images were then analyzed.

\section{Effect of carbon weight}

Carbon, in amounts of 10, 30, 50, 70 and $90 \mathrm{mg}$, was added to $25 \mathrm{~mL}$ of $100 \mathrm{ppm} \mathrm{Cd}$ (II) solution and then shaken for 60 minutes. The mixture was then filtered using vacuum filtration. The filtrate was then examined by AAS to find out the remaining concentration after the absorption process. The absorbed concentration was calculated using the calibration curve method.

\section{RESULTS AND DISCUSSION Carbon characterization}

In this study, a carbon material was obtained from banana fruit peels and stems. The charcoal was produced by pyrolysis. The characterization of the obtained material was performed in accordance with Indonesian National Standard SNI 06-3730-1995 with regard to technical active charcoal. ${ }^{30}$ The determined parameters were the moisture content, ash content and iodine number. The characteristics of the banana peel and stem carbon materials are listed in Table 1.

\section{Carbon yield}

Carbon yield was determined to find out the amount of carbon that can be produced from samples of banana fruit peels and stems. The data in Table 1 indicate that the yield of carbon decreased with increasing carbonization temperature. When carbonized at $400{ }^{\circ} \mathrm{C}$ for 30 minutes, the banana peels yielded $60.93 \%$ carbon, but only $55.61 \%$ when carbonized at a higher temperature of $450-500{ }^{\circ} \mathrm{C}$. The same situation occurred in the case of the banana stems. The carbon yield decreased from $65.38 \%$ to $56.97 \%$, for the carbonization temperature of $400{ }^{\circ} \mathrm{C}$ and $450{ }^{\circ} \mathrm{C}$. This result was similar to that observed regarding the effect of carbonization temperature and time of bamboo. ${ }^{21}$ The decrease of the yield was caused by the decomposition of cellulose, hemicelluloses and lignocellulose. ${ }^{31}$

\section{Moisture content}

The moisture content of the obtained materials was determined to find out about the hygroscopic nature of carbon. Table 1 shows that the moisture content of the carbon from banana stems is higher than that of the carbon achieved from banana peels. The results regarding the moisture content in this study are relatively small, because both carbon materials meet the Indonesian National Standard regarding active charcoal quality, which imposes a maximum of $15 \%$.

Table 1

Carbon characterization

\begin{tabular}{|c|c|c|c|c|c|}
\hline \multicolumn{2}{|c|}{ Carbonization process } & $\begin{array}{c}\text { Carbon } \\
\text { yield }(\%)\end{array}$ & $\begin{array}{c}\text { Moisture } \\
\text { content }(\%)\end{array}$ & $\begin{array}{c}\text { Ash content } \\
(\%)\end{array}$ & $\begin{array}{l}\text { Iodine number } \\
(\mathrm{mg} / \mathrm{g})\end{array}$ \\
\hline \multirow{3}{*}{$\frac{\infty}{0}$} & $400{ }^{\circ} \mathrm{C}, 30 \mathrm{~min}$ & 60.93 & 7.010 & 4.559 & 994.05 \\
\hline & $450{ }^{\circ} \mathrm{C}, 10 \mathrm{~min}$ & 55.16 & 5.371 & 7.228 & 1006.74 \\
\hline & $500{ }^{\circ} \mathrm{C}, 10 \mathrm{~min}$ & 50.17 & 5.282 & 11.035 & 998.28 \\
\hline \multirow{3}{*}{$\frac{\mathscr{E}}{\tilde{\omega}}$} & $400{ }^{\circ} \mathrm{C}, 30 \mathrm{~min}$ & 65.38 & 4.953 & 7.737 & 998.28 \\
\hline & $450{ }^{\circ} \mathrm{C}, 10 \mathrm{~min}$ & 56.97 & 4.172 & 9.650 & 1019.43 \\
\hline & $500{ }^{\circ} \mathrm{C}, 10 \mathrm{~min}$ & 45.81 & 3.444 & 13.852 & 989.82 \\
\hline
\end{tabular}


This indicated that the moisture in both samples was evaporated during the carbonization process and its content tends to decrease with increasing carbonization temperature. Based on the results obtained, it can be concluded that the carbon produced from both samples have hygroscopic properties, which means that the carbon materials have the ability to adsorb gases or liquids. ${ }^{32}$

\section{Ash content}

The ash content was determined with the aim to measure the amount of metal oxides in the carbon. Metal oxides are minerals contained in the initial samples, such as clay, silica, calcium and magnesium oxide, which remain after the carbonization process. The data in Table 1 indicate that, as the temperature increased, there was an increase in the ash content. The banana peel carbon produced in this study had relatively low ash content, compared to that of the carbon from banana stems. The ash content at carbonization temperatures of $400{ }^{\circ} \mathrm{C}$ and $450{ }^{\circ} \mathrm{C}$ met the char quality standards set by the Indonesian National Standard (SNI), which requires maximum $10 \%$, but the carbon produced at a temperature of $500{ }^{\circ} \mathrm{C}$ exceeded the maximum SNI limit. It was remarked that the content of metal oxides after the carbonization process was high. The ash content in carbon can affect its adsorption ability, because ash can block the pores, covering the active sites. ${ }^{33}$

\section{Iodine number}

The iodine number was determined in order to measure the surface area of carbon. Iodine number is defined as the milligrams of iodine that can be adsorbed by one gram of carbon. Iodine number can be used as a representation of the surface area of carbon due to the relationship between iodine number and surface area that forms a single layer (monolayer) on the carbon surface. $^{34}$ The data in Table 1 show that the iodine number of the two carbon materials rises with increasing carbonization temperature. It can be seen that the carbon obtained from the banana stems had a fairly high iodine number, when compared to that of the carbon from banana peels. The iodine number of banana stem carbon, when carbonized at $400{ }^{\circ} \mathrm{C}$ for 30 minutes, was 998.28 $\mathrm{mg} / \mathrm{g}$, and rose to $1019.43 \mathrm{mg} / \mathrm{g}$, when the material was carbonized at a higher temperature of $450{ }^{\circ} \mathrm{C}$. Meanwhile, when the carbonization temperature of $500{ }^{\circ} \mathrm{C}$ was used, the iodine number decreased to $989.82 \mathrm{mg} / \mathrm{g}$. This decrease occurred because of the high ash content that was produced in carbon at this temperature. It was concluded that the ash had covered the surface and the pores of the carbon material, so that the iodine absorption by the carbon decreased. ${ }^{33}$

\section{Morphological characterization of pores}

The surface morphology of the carbon materials was characterized by SEM-EDS at a magnification of 750x. Figures 1 and 2 show microscopy images of the banana peel carbon and banana stem carbon, respectively. Both materials were prepared at different temperatures. Some pores can be observed on the banana peels carbonized at $400{ }^{\circ} \mathrm{C}$ (Fig. 1a), while more pores were formed at a higher temperature of $450{ }^{\circ} \mathrm{C}$ (Fig. 1b). These images indicate the occurrence of pore growth as the carbonization temperature was increased from $400{ }^{\circ} \mathrm{C}$ to $450{ }^{\circ} \mathrm{C}$. However, in the case of the carbon formed at the temperature of $500{ }^{\circ} \mathrm{C}$, the pores were no longer visible on the carbon surface (Fig. 1c). This is allegedly related to the ash content in the carbon and also to decreased pore size when the temperature rose to $500{ }^{\circ} \mathrm{C}$ and above. This result is in accordance with those of previous studies on the effect of carbonization temperature and time on the characteristics of carbon prepared from bamboo and coconut fiber. ${ }^{19,29}$

The EDS data listed in Table 2 reveal the elemental composition of the carbon materials (comprising $\mathrm{C}, \mathrm{O}, \mathrm{Na}, \mathrm{Mg}, \mathrm{Al}, \mathrm{Si}, \mathrm{Cl}$, and $\mathrm{K}$ ), with the relative mass percentage of different elements for each carbon material, as a function of the carbonization temperature. The $\mathrm{C}$ element is a dominating element, reaching $\pm 79 \%$ in the banana peel carbon. In addition, $\mathrm{O}$ also had a high percentage, of $\pm 17 \%$, in the same material. Meanwhile, the composition of the carbon from banana stems varied greatly with each carbonization temperature level, which can be explained by the working principle of the SEMEDS instrument, which detected certain areas hit by electrons. $^{35}$

\section{Effect of carbon weight on adsorption capacity}

In this study, carbon materials were prepared from banana peels and banana stems to serve as adsorbents. The amount (weight) of the adsorbent is an important factor influencing the adsorption process. This is because the amount of carbon 
indicates the number of adsorbent particles that could adsorb the adsorbate at a certain concentration. Various amounts of the adsorbent were used in the experiments: $10 \mathrm{mg}, 30 \mathrm{mg}, 50$ $\mathrm{mg}, 70 \mathrm{mg}$ and $90 \mathrm{mg}$. The variation of carbon weight was expected to indicate the optimum amount of carbon that can be used to adsorb metal ions of $\mathrm{Cd}(\mathrm{II})$. The measurement was carried out at room temperature. The $\mathrm{pH}$ of the solution was adjusted to 5 , the contact time was 60 minutes, and the initial concentration of cadmium was 100 $\mathrm{ppm}$. The choice of the $\mathrm{pH}$ value was based on the maximum value of cadmium metal solubility to form $\mathrm{Cd}^{2+}$ species in distilled water, in accordance with the Pourbaix diagram. The effect of contact time on the adsorption of cadmium (Cd) and lead $(\mathrm{Pb})$ was studied previously and was established to be about $60 \mathrm{~min}$ for various activated carbon materials. ${ }^{36}$

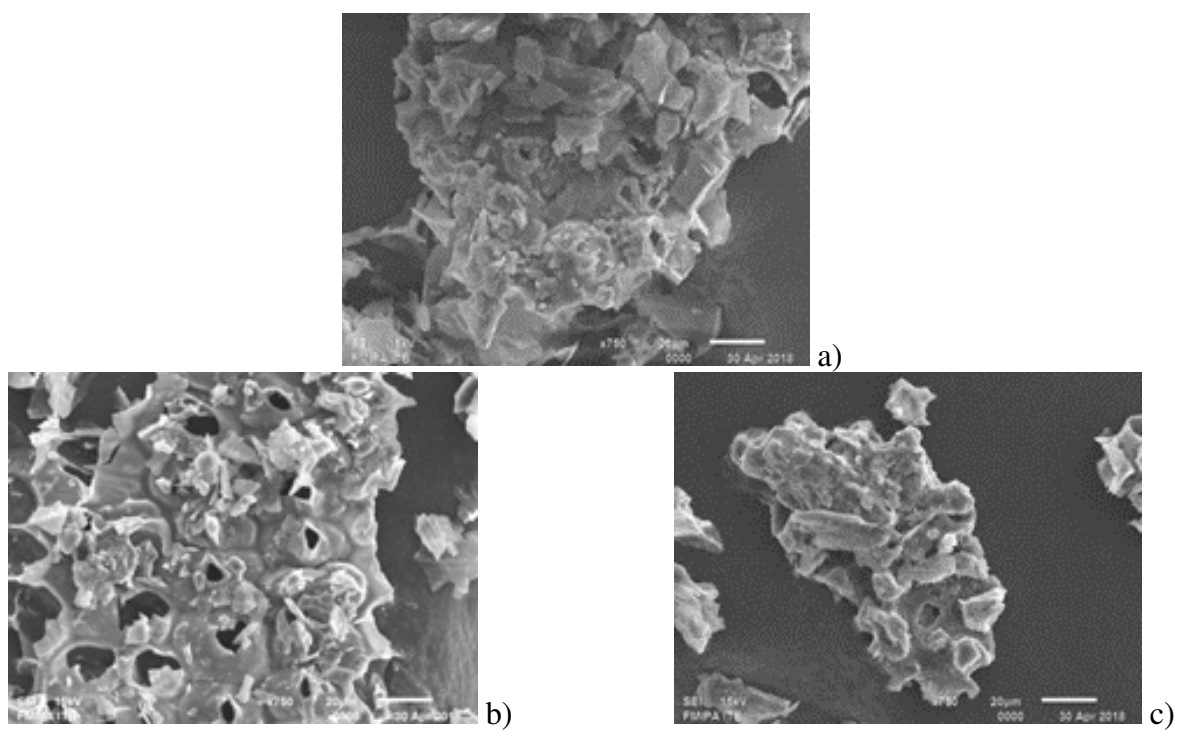

Figure 1: Surface morphology of banana peel carbon material prepared at $400{ }^{\circ} \mathrm{C}(\mathrm{a}), 450{ }^{\circ} \mathrm{C}(\mathrm{b})$ and $500{ }^{\circ} \mathrm{C}(\mathrm{c})$

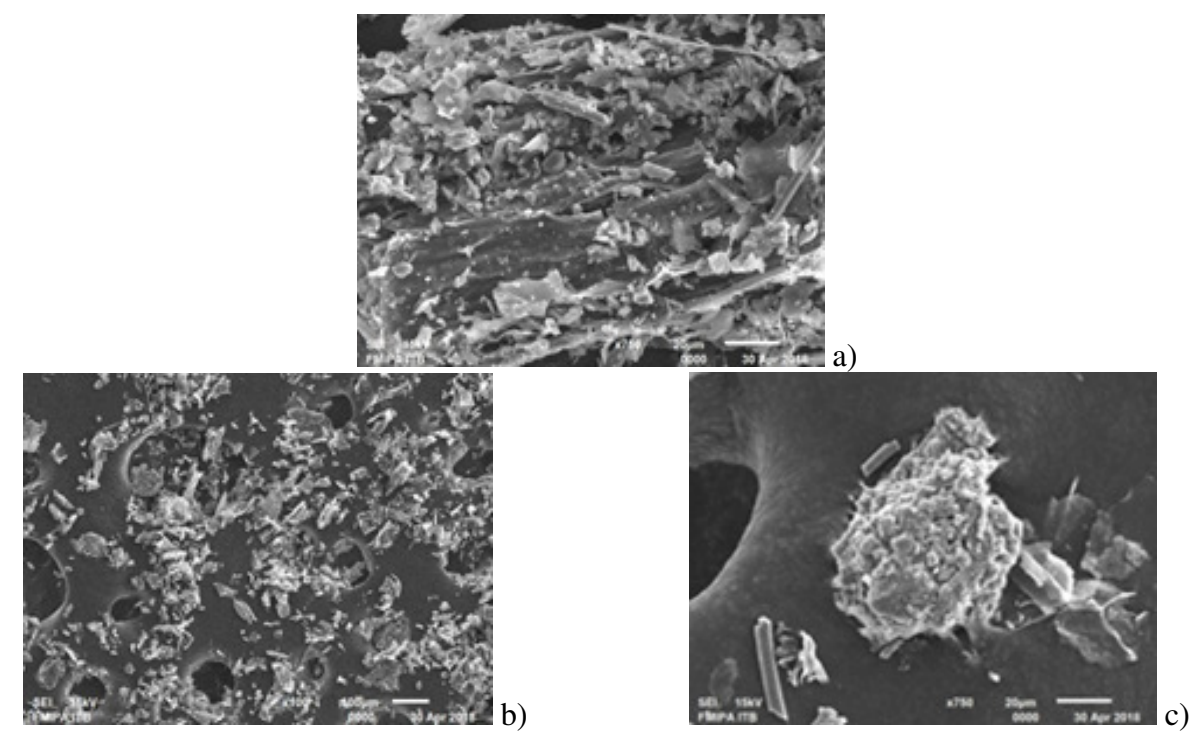

Figure 2: Surface morphology of banana stem carbon material prepared at $400{ }^{\circ} \mathrm{C}(\mathrm{a}), 450{ }^{\circ} \mathrm{C}(\mathrm{b})$ and $500{ }^{\circ} \mathrm{C}(\mathrm{c})$ 
Table 2

Elemental composition of banana peel and stem carbon materials

\begin{tabular}{lcccccc}
\hline Element & \multicolumn{3}{c}{ Banana peels } & \multicolumn{3}{c}{ Banana stems } \\
\cline { 2 - 7 } & $400{ }^{\circ} \mathrm{C}$ & $450{ }^{\circ} \mathrm{C}$ & $500{ }^{\circ} \mathrm{C}$ & $400{ }^{\circ} \mathrm{C}$ & $450{ }^{\circ} \mathrm{C}$ & $500{ }^{\circ} \mathrm{C}$ \\
\hline $\mathrm{C}$ & 79.00 & 78.50 & 79.31 & 70.76 & 65.76 & 43.02 \\
$\mathrm{O}$ & 17.49 & 17.75 & 16.72 & 23.97 & 28.41 & 45.18 \\
$\mathrm{Na}$ & 0.04 & 0.04 & 0.00 & 0.00 & 0.00 & 0.43 \\
$\mathrm{Mg}$ & 0.24 & 0.19 & 0.21 & 0.37 & 0.69 & 0.54 \\
$\mathrm{Al}$ & 0.10 & 0.06 & 0.00 & 0.00 & 0.39 & 2.07 \\
$\mathrm{Si}$ & 0.62 & 1.23 & 0.53 & 0.00 & 1.51 & 5.54 \\
$\mathrm{Cl}$ & 0.13 & 0.11 & 0.17 & 0.52 & 0.38 & 0.28 \\
$\mathrm{~K}$ & 2.38 & 2.11 & 3.05 & 3.53 & 2.45 & 2.93 \\
$\mathrm{Ca}$ & 0.00 & 0.00 & 0.00 & 0.85 & 0.42 & 0.00 \\
\hline
\end{tabular}

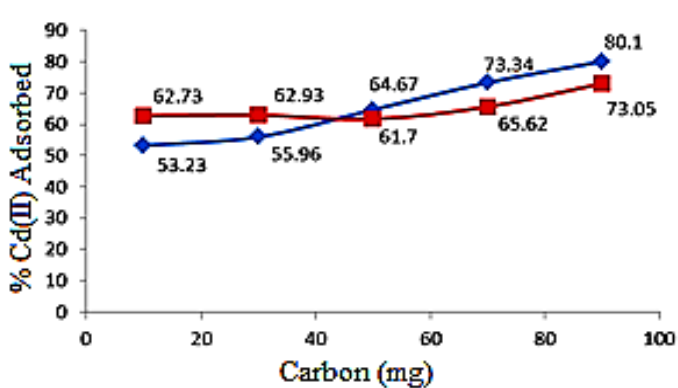

Figure 3: Cd(II) adsorption onto banana peel carbon prepared at $450{ }^{\circ} \mathrm{C}$ (blue $\left.\diamond\right)$, and at $500{ }^{\circ} \mathrm{C}$ (red $\square$ ) as a function of adsorbent weight

Figures 3 and 4 show that the adsorption of $\mathrm{Cd}(\mathrm{II})$ ions by the banana peel and banana stem carbon materials was affected by the weight of the adsorbent. Based on the data presented in Figure 3 , the banana peel carbon $\left(450{ }^{\circ} \mathrm{C}-\right.$ blue line $)$ showed an increase of $\mathrm{Cd}$ metal adsorption from $53.23 \%$ to $80.1 \%$ with the increase in adsorbent weight from $10 \mathrm{mg}$ to $90 \mathrm{mg}$, respectively. Similar results were remarked for the carbon prepared from banana stems at temperatures of $450{ }^{\circ} \mathrm{C}$ and $500{ }^{\circ} \mathrm{C}$ (Fig. 4). The increase in absorption was due to the increase in the amount of the adsorbent, which allowed higher interaction with cadmium. A higher amount of the adsorbent would produce a more effective interaction between the active sites of the negatively charged adsorbent cell walls and the positively charged cadmium ions, in other words, the higher the amount of the adsorbent, the more active carbon will react. ${ }^{7,37}$

It should be also noted that when the mass of the adsorbent was increased, the adsorption efficiency also increased, but a decline in the adsorption capacity occurred. ${ }^{36}$ The adsorption capacity is the amount of cadmium that can accumulate on the surface of the adsorbent. This

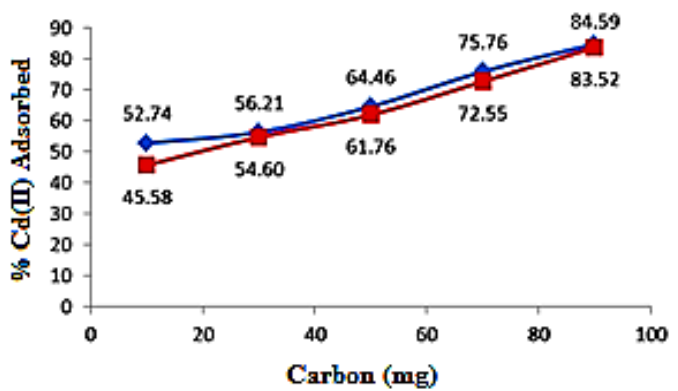

Figure 4: $\mathrm{Cd}(\mathrm{II})$ adsorption onto banana stem carbon prepared at $450{ }^{\circ} \mathrm{C}$ (blue $\diamond$ ), and at $500{ }^{\circ} \mathrm{C}$ (red $\square$ ) as a function of adsorbent weight

was found from the results listed in Tables 3 and 4 , which reveal that the adsorption capacity continues to diminish with the increase in the amount of the adsorbent used. ${ }^{38}$ The effect of activated carbon adsorbent dosage on $\mathrm{Cd}^{2+}$ adsorption was also investigated previously and it was shown that the adsorption was high at the initial concentration of the adsorbent, but saturation occurred and the curve leveled off, indicating the independence of the adsorption of the adsorbent concentration. ${ }^{20}$ The carbon material from banana peels carbonized at $500{ }^{\circ} \mathrm{C}$ for 10 minutes exhibited a different absorption pattern. At the adsorbent weight of $10 \mathrm{mg}$ to 30 $\mathrm{mg}$, there was an increase in adsorption from $62.73 \%$ to $62.93 \%$, then followed a decrease at the $50 \mathrm{mg}$ weight of the adsorbent, showing $61.70 \%$ adsorption. This indicates that the carbon underwent desorption, which is the action of releasing the metal ion that has been adsorbed. This means that the adsorbent was saturated, so it was unable to adsorb more metal ions because all the active groups were already bound to metal ions in the solution. In this case, equilibrium was reached when the concentration of metal ions in the liquid phase was equal to the concentration of 
metal ions in the adsorbent phase. ${ }^{38}$ Based on the data above, it can be noted that the optimum dosage of the four carbon materials to adsorb cadmium metal could not be determined, because the maximum adsorption point was not reached, as the adsorption curves continue to increase with the increase in the adsorbent weight. Kinetic studies on cadmium(II) adsorption have been reported. ${ }^{39}$ The process was described as pseudosecond order sorption, with a rapid kinetic profile - within 30 minutes. The kinetics of cadmium(II) adsorption onto the banana waste carbon materials developed here will be investigated in our further research work.

Table 3

Adsorption capacity of banana peel carbon as a function of adsorbent weight

\begin{tabular}{|c|c|c|}
\hline $\begin{array}{l}\text { Carbonization } \\
\text { temperature and time }\end{array}$ & $\begin{array}{l}\text { Adsorbent weight } \\
(\mathrm{mg})\end{array}$ & $\begin{array}{l}\text { Adsorption capacity } \\
(\mathrm{mg} / \mathrm{g})\end{array}$ \\
\hline \multirow{5}{*}{$450{ }^{\circ} \mathrm{C}, 10 \mathrm{~min}$} & 10 & 133.0834 \\
\hline & 30 & 46.6314 \\
\hline & 50 & 32.3335 \\
\hline & 70 & 26.1911 \\
\hline & 90 & 22.2513 \\
\hline \multirow{5}{*}{$500^{\circ} \mathrm{C}, 10 \mathrm{~min}$} & 10 & 156.8176 \\
\hline & 30 & 52.4445 \\
\hline & 50 & 30.8476 \\
\hline & 70 & 23.4344 \\
\hline & 90 & 20.2906 \\
\hline
\end{tabular}

Table 4

Adsorption capacity of banana stem carbon as a function of adsorbent weight

\begin{tabular}{lcc}
\hline $\begin{array}{l}\text { Carbonization } \\
\text { temperature and time }\end{array}$ & $\begin{array}{c}\text { Adsorbent weight } \\
(\mathrm{mg})\end{array}$ & $\begin{array}{c}\text { Adsorption capacity } \\
(\mathrm{mg} / \mathrm{g})\end{array}$ \\
\hline & 10 & 131.8451 \\
$450{ }^{\circ} \mathrm{C}, 10 \mathrm{~min}$ & 30 & 46.8377 \\
& 50 & 32.2303 \\
& 70 & 27.0560 \\
& 90 & 23.4972 \\
\hline $500{ }^{\circ} \mathrm{C}, 10 \mathrm{~min}$ & 10 & 113.9584 \\
& 30 & 45.4962 \\
& 50 & 30.8819 \\
& 70 & 25.9110 \\
\hline
\end{tabular}

\section{CONCLUSION}

Carbon materials were prepared from banana peels and banana stems by two stages of carbonization: carbonization was first carried out at $400{ }^{\circ} \mathrm{C}$ for 30 minutes and then continued at $450{ }^{\circ} \mathrm{C}$ and $500{ }^{\circ} \mathrm{C}$ for 10 minutes. The carbon content in the materials was determined for the different carbonization temperatures, of $400{ }^{\circ} \mathrm{C}$, $450{ }^{\circ} \mathrm{C}$ and $500{ }^{\circ} \mathrm{C}$, and indicated carbon yields of $60.92 \%, 55.16 \%$ and $50.11 \%$, for the banana peels, and of $65.37 \%, 56.97 \%$ and $45.80 \%$, for the banana stems, respectively. The moisture content of the banana peel carbon was $7.01 \%, 5.37 \%$ and
$5.28 \%$, respectively, for each carbonization temperature level, and that of the banana stem carbon was $4.93 \%, 4.17 \%$ and $3.44 \%$, respectively. The ash content was $4.56 \%, 7.23 \%$ and $11.04 \%$, for the banana peel, and of $7.73 \%$, $9.65 \%$ and $13.85 \%$, for the banana stems, respectively. The highest iodine number for the banana peel carbon $\left(450{ }^{\circ} \mathrm{C}\right)$ was $1006.74 \mathrm{mg} / \mathrm{g}$, while that for the banana stem carbon $\left(450{ }^{\circ} \mathrm{C}\right)$ was $1019.43 \mathrm{mg} / \mathrm{g}$. The surface morphology of the adsorbent materials was significantly different, as a function of the carbonization temperature levels. The carbonization temperature 
of $450{ }^{\circ} \mathrm{C}$ for 10 minutes was considered as the optimum condition for preparing carbon adsorbent from both banana peels and banana stems, because the materials prepared at this temperature met active charcoal quality standards (SNI 06-3730-95). The adsorption ability of the prepared charcoal materials as a function of the adsorbent dosage used indicated that the increase in adsorbent weight increases the concentration of the absorbed cadmium.

ACKNOWLEDGMENTS: The authors thank Yoga Nata Kusuma for his contribution to the preliminary research. The support of the laboratory assistants of Chemistry Education Laboratory is highly appreciated.

\section{REFERENCES}

1 H. Duan, H. Zhang, Q. Huang, Y. Zhang and M. $\mathrm{Hu}$, Ocean Coast. Manag., 130, 128 (2016), https://doi.org/10.1016/j.ocecoaman.2016.06.006 2 A. Priya and S. Hait, Process Saf. Environ. Prot., 116, 74

(2018),

https://doi.org/10.1016/j.psep.2018.01.018

3 R. Cao, Y. Liu, Q. Wang, Z. Dong, D. Yang et al., Sci. Total Environ., 642, 809 (2018), https://doi.org/10.1016/j.scitotenv.2018.06.126

4 B. Kambuaya, Peraturan Menteri Lingkungan Hidup, 5, 16 (2014).

5 N. S. Randhawa, K. Gharami and M. Kumar, Hydrometallurgy, $\quad \mathbf{1 6 5}, \quad 191 \quad$ (2016), https://doi.org/10.1016/j.hydromet.2015.09.011

6 Y. F. Chang, J. F. Wen, J. F. Cai, W. Xiao-Ying, L. Yang et al., Forensic Sci. Int., 220, 1 (2012), doi: 10.1016/j.forsciint.2012.01.032

7 A. H. A. Mahvi, D. Naghipour, F. Vaezi and S. Nazmara, Am. J. Appl. Sci., 2, 372 (2005).

8 S.-J. Dai, D.-Z. Wei and D. Q. Zhou, Trans. Nonferrous Met. Soc. China, 18, 1008 (2008), https://doi.org/10.1016/S1003-6326(08)60173-9

9 F. Sardella, M. Gimenez, C. Navasa, C. Morandi, C. Deiana et al., J. Environ. Chem. Eng., 3, 253 (2015), https://doi.org/10.1016/j.jece.2014.06.026

10 K. V. Mahindrakar and V. K. Rathod, Environ. Technol. Innov., 11, $371 \quad$ (2018), https://doi.org/10.1016/j.eti.2018.06.015

11 D. Yu, L. Wang and M. Wu, J. Taiwan Inst. Chem. Eng., $\quad$ 93, $543 \quad$ (2018), https://doi.org/10.1016/j.jtice.2018.08.038

12 M. Napitupulu, D. K. Walanda, Y. Natakusuma, M. Basir and Mahfudz, J. Surf. Sci. Technol., 34, 30 (2018), https://doi.org/10.18311/jsst/2018/11055

13 K. Podala, D. K Walanda and M. Napitupulu, $J$. Akad. Kim., 4, 136 (2015).

14 R. C Pongenda, M. Napitupulu and D. K. Walanda, J. Akad. Kim., 4, 84 (2015).
15 W. Cai, Z. Li, J. Wei and Y. Liu, Chem. Eng. Res. Des., $\quad 140, \quad 23 \quad$ (2018), https://doi.org/10.1016/j.cherd.2018.10.008

16 W. Cai, J. Wei, Z. Li, Y. Liu, J. Zhou et al., Colloid. Surf. Physicochem. Eng. Asp., 563, 102 (2019), https://doi.org/10.1016/j.colsurfa.2018.11.062

17 B. Berrima, W. Maatar, G. Motha, S. Boufi, L. El Aloui et al., Cellulose Chem. Technol., 50, 701 (2016), http://www.cellulosechemtechnol.ro/pdf/CCT56(2016)/p.701-709.pdf

18 A. Zukal, M. Shamzhy, M. Kubů and J. Čejka, J. CO2 Util., $\quad \mathbf{2 4}, \quad 157 \quad$ (2018), https://doi.org/10.1016/j.jcou.2017.12.016

19 S. Subyakto, I. Budiman and G. Pari, Wood Res. J., 3, 68 (2012).

${ }^{20}$ S. Xu, W. Yu, S. Liu, C. Xu, J. Li et al., Sustainability, $\quad 10, \quad 4250 \quad$ (2018), doi:10.3390/su10114250

21 Z. Chen, H. Zhang, C. Wu, L. Luo, C. Wang et al., Desalination, 433, 68 (2018), https://doi.org/10.1016/j.desal.2017.11.036

${ }^{22}$ L. D. Benefield, J. F. Judkins and B. L. Weand, "Process Chemistry for Water and Wastewater Treatment", Prentice-Hall, Englewood Cliffs, USA, 1982.

23 E. L. K. Mui, W. H. Cheung, M. Valix and G. McKay, Sep. Purif. Technol., 74, 213 (2010), https://doi.org/10.1016/j.seppur.2010.06.007

${ }^{24}$ W. Cai, S. Zhang, X. Hu and M. Jaroniec, Energ. Fuels, 32, $9701 \quad$ (2018), https://doi.org/10.1021/acs.energyfuels.8b02097

25 P. S. Vassileva, A. K. Detcheva, T. Hr. Radoykova, I. A. Avramova, K. I. Aleksieva et al., Cellulose Chem. Technol., $\quad 52, \quad 633 \quad$ (2018), http://www.cellulosechemtechnol.ro/pdf/CCT7-

8(2018)/p.633-643.pdf

26 C. Dong, F. Zhang, Z. Pang and G. Yang, Carbohyd. Polym., 151, 230 (2016), doi: 10.1016/j.carbpol.2016.05.066

27 H. Husni, S. Supriandy, B. Yusri and J. Sulaiman, in Procs. National Conference on Chemical Engineering Sciences and Applications (CHESA), Aceh, Indonesia, 2004.

28 F. Meng, G. Wang, X. Dua, Z. Wang, S. Xu et al., Compos. B Eng., 160, $341 \quad$ (2019), https://doi.org/10.1016/j.compositesb.2018.08.048

${ }_{29}$ I. Budiman, A. Maddu, G. Pari and S. Subyakto, J. Ilmu dan Teknol. Kayu Trop., 11, 101 (2017).

30 BSN Indonesia, SNI. SNI 06-3730-1995, 1995.

31 Z. Song-Lin, G. Shang-Yu, Y. Xi-Gen and X. BoSen, J. For. Res., 14, 75 (2003).

32 W-H. Chen, B-J. Lin, B. Colin, J.-S. Chang, A. Pétrissans et al., Appl. Energ., 231, 768 (2018), https://doi.org/10.1016/j.apenergy.2018.09.135

${ }_{33}$ Y. Feng, W. Yang and W. Chu, Int. J. Chem. Eng., 5, 1 (2014).

34 H. Jankowska, A. Swiatkowski and J. Choma, "Active Carbon", Ellis Horwood, West Sussex, UK; Prentice-Hall, Englewood Cliffs, USA, 1991. 
${ }^{35}$ R. E. Smallman and R. J. Bishop, "Metalurgi Fisik Modern dan Rekayasa Material", Erlangga, Jakarta, Indonesia, 2000.

36 U. I. Gaya, E. Otene and A. H. Abdullah, SpringerPlus, $\quad 4, \quad 458 \quad$ (2015), https://doi.org/10.1186/s40064-015-1256-4

${ }^{37}$ J. Anwar, U. Shafique, W.-U. Zaman, M. Salman, A. Dara et al., Bioresour. Technol., 101, 1752 (2010), https://doi.org/10.1016/j.biortech.2009.10.021

38 Marlinawati, B. Yusuf and Alimuddin, J. Kim. Mulawarman, 13, 23 (2015).

${ }^{39}$ E. Asuquo, A. Martin, P. Nzerem, F. Siperstein and X. Fan, J. Environ. Chem. Eng., 5, 679 (2017), https://doi.org/10.1016/j.jece.2016.12.043 